\title{
Bacterial Communities Associated with the Cycling of Non-Starch Polysaccharides and Phytate in Aquaponics Systems
}

\author{
Daniel Menezes-Blackburn ${ }^{1, *,+}{ }^{\mathbb{D}}$, Nahad Al-Mahrouqi ${ }^{1,+}{ }^{+}$, Buthaina Al-Siyabi ${ }^{1}$, Adhari Al-Kalbani ${ }^{1}$, \\ Ralf Greiner ${ }^{2}$ and Sergey Dobretsov ${ }^{3,4}$ (D) \\ 1 Department of Soils, Water and Agricultural Engineering, Sultan Qaboos University, P.O. Box 34, \\ Muscat 123, Oman; s101845nm@gmail.com (N.A.-M.); buthsa@squ.edu.om (B.A.-S.); \\ s128490@student.squ.edu.om (A.A.-K.) \\ 2 Department of Food Technology and Bioprocess Engineering, Max Rubner-Institut, Federal Research Institute \\ of Nutrition and Food, 76131 Karlsruhe, Germany; ralf.greiner@mri.bund.de \\ 3 Department of Marine Science and Fisheries, Sultan Qaboos University, P.O. Box 34, Muscat 123, Oman; \\ sergey@squ.edu.om \\ 4 Centre of Excelence in Marine Biotechnology, Sultan Qaboos University, P.O. Box 50, Muscat 123, Oman \\ * Correspondence: danielblac@squ.edu.om; Tel.: +968-2414-3668 \\ + Co-first authorship - the first two authors contributed equally to this manuscript.
}

check for updates

Citation: Menezes-Blackburn, D.; Al-Mahrouqi, N.; Al-Siyabi, B.; Al-Kalbani, A.; Greiner, R.; Dobretsov, S. Bacterial Communities Associated with the Cycling of Non-Starch Polysaccharides and Phytate in Aquaponics Systems. Diversity 2021, 13, 631. https:/ / doi.org/10.3390/d13120631

Academic Editor: Wenzhi Liu

Received: 31 October 2021

Accepted: 25 November 2021

Published: 30 November 2021

Publisher's Note: MDPI stays neutral with regard to jurisdictional claims in published maps and institutional affiliations.

Copyright: (c) 2021 by the authors. Licensee MDPI, Basel, Switzerland. This article is an open access article distributed under the terms and conditions of the Creative Commons Attribution (CC BY) license (https:// creativecommons.org/licenses/by/ $4.0 /)$.
Abstract: Aquaponics are efficient systems that associate aquatic organisms' production and plants by recirculating water and nutrients between aquaculture and hydroponic tanks. In this study, we characterised the bacterial communities in the freshwater aquaponics system that can mineralise polysaccharides and phytate by producing carbohydrate-degrading enzymes and phytases, by $16 \mathrm{~S}$ rRNA gene sequencing and in vitro culture techniques. Around $20 \%$ of the operational taxonomic units (zOTUs) identified were previously reported to carry fibre-degrading enzyme putative genes, namely $\beta$-glucanase $(1 \%)$, xylanase $(5 \%)$, or cellulases $(17 \%)$. Ten $\%$ of the zOTUs were previously reported to carry putative genes of phytases with different catalytic mechanisms, namely $\beta$-propeller $(6 \%)$, histidine acid phytases $(3 \%)$, and protein tyrosine phytase $(<1 \%)$. Thirty-eight morphologically different bacteria were isolated from biofilms accumulated in fish and plant compartments, and identified to belong to the Bacilli class. Among these, 7 could produce xylanase, 8 produced $\beta$ glucanase, 14 produced cellulase, and 11 isolates could secrete amylases. In addition, Staphylococcus sp. and Rossellomorea sp. could produce consistent extracellular phytate-degrading activity. The PCR amplification of $\beta$-propeller genes both in environmental samples and in the isolates obtained showed that this is the most ecologically relevant phytase type in the aquaponics systems used. In summary, the aquaponics system is abundant with bacteria carrying enzymes responsible for plant-nutrient mineralisation.

Keywords: aquaponics; metabarcoding; bacterial communities; carbohydrases; phytases

\section{Introduction}

Aquaponics is a sustainable closed-loop recirculating aquaculture system (RAS), combined with hydroponic crops, where the integrated production of plants and aquatic animals can be achieved [1-3]. There is a variety of salt and freshwater fish, invertebrates, and plant species that can be cultivated in aquaponics systems, including tilapia, catfish, finfish, flatfish, shrimp, sea urchin, and several types of plants, like culinary herbs, lettuce, algae, and fruiting crops [4].

Aquaponics systems have recently received high interest from the general public due to their ability to produce fish and vegetables in small areas simultaneously, drastically improving water management compared to when hydroponics and aquaculture are carried 
out independently [5,6]. Additionally, it reduces the cost of effluent treatment and the environmental impact of water nutrient pollution resulting from agriculture and aquaculture production activities [2,7].

Water and biofilm microorganisms present in aquaponics systems have an essential role in the nutrient cycling from fish faecal matter and their bioavailability to plants $[8,9]$. In aquaponics systems, heterotrophic microorganisms use undigested fish feed as an organic energy source, while chemo-litho-autotrophic nitrifiers utilise dissolved ammonia instead [10]. These microorganisms play an important role in converting fish organic wastes into valuable plant nutrients (e.g., $\mathrm{PO}_{4}{ }^{-}, \mathrm{NH}_{4}{ }^{+}, \mathrm{NO}_{3}{ }^{-}$) which can then be taken up by plants in their ionic forms, eliminating the need for plant fertiliser inputs [11]. Aquaponics systems display diverse microniches for the growth of microbial populations [8,12]. Due to different types of cultivated fish and plants, characteristics of water, design of fish and plant compartments, nutrient composition, and temperature of effluents, diverse microbial communities carry out the cycling of various nutrients on this system [2,13].

On the other hand, non-starch polysaccharides (NSPs) and phytate are among the main challenges when plant-based fish feed is used [14-16]. Plant-based feeds have a high phytate content, and fish cannot efficiently utilise phytate [17]. This leads to the excretion of phytate into the water, resulting in nutrient pollution, algal growth, and hypoxic environments [18]. However, water microorganisms carrying extracellular phytases can mineralise phytate present in the fish feed $[19,20]$. Fish diets can also be supplemented with phytase to increase phosphorus availability and decrease phytate anti-nutrient activity [21].

Fish feeds are rich in indigestible fibre that can only be degraded after excretion by an array of water and biofilm microbes, making the aquaponics systems an interesting environment to study bacterial strains that produce non-starch polysaccharide (NSP)degrading enzymes. Fish lack the enzymes capable of hydrolysing the NSP $\beta$-glycosidic bonds [22]. Similarly to phytases, exogenous carbohydrases can be supplemented with plant-based fish feed to increase NSP digestibility, increase feed energy value, and decrease NSP anti-nutrient activity [15]. Both phytate- and NSP-degrading enzymes are highly valued as feed additives, and aquaponics systems represent a possible source of new enzymes with improved properties compared to the ones available in the market [15]. However, most microbial studies in aquaponics systems focused on ammonia and nitrite oxidiser bacteria, or on the presence of pathogens [8].

The present study aimed to investigate the diversity of bacterial communities associated with phytate and NSP mineralisation in an aquaponics system using MiSeq 16S rRNA $\mathrm{V} 4$ gene sequencing, together with isolation and the screening of bacterial strains capable of secreting cellulase, xylanase, $\beta$-glucanase, and phytase enzymes.

\section{Materials and Methods}

\subsection{Aquaponics System and Samples Collection}

An outdoor aquaponics system was installed at Sultan Qaboos University, Muscat, Oman $\left(23.5896^{\circ} \mathrm{N}, 58.1735^{\circ} \mathrm{E}\right)$. It was composed of three compartments: one fish tank with 4 Nile tilapia (Oreochromis niloticus, average length $20 \mathrm{~cm}$ ) connected to a hydroponic unit (plant compartment), and a water treatment unit. The water from the fish tank was used to grow lettuce (Lactuca sativa) hydroponically. Each aquaponics unit contained 10 lettuce plants floating in the surface of the water in the plant compartment. The treatment unit was used to maintain the water quality in an optimal range. It had a sand filter that removed solids from the water, a biological filter (Bactoballs ${ }^{\circledR}$, Maníkovice, Czech Republic) that removed ammonia, and a pump that pumped the water back to the fish tank. The total volume of each aquaponics unit was $600 \mathrm{~L}$ and the flow rate used was $1 \mathrm{~L} \mathrm{~min}{ }^{-1}$. The outdoor aquaponics system was shaded to reduce natural sunlight, and had an average light intensity of $100 \mu \mathrm{mol} \mathrm{m} \mathrm{m}^{-2} \mathrm{~s}^{-1}$ during the experiment. Three replicated identical aquaponics units were used in this study, independently sampled and analysed.

The biofilm/water samples were collected on 23 January 2020, and the aquaponics systems ran for one month before sampling. Biofilms accumulated on the walls of fish 
and plant compartments were scraped using a sterile spatula. Biofilms samples were collected in multiple locations of each compartment. Three aquaponics units were sampled independently. Biofilms samples suspended with site water from the corresponding compartment in a sterile $15 \mathrm{~mL}$ centrifuge tube (Falcon) were homogenised to obtain a representative sample. For the plant compartment samples, biofilms associated with the root of lettuce were also collected. Then, collected biofilm samples were freshly assayed.

In addition, $50 \mathrm{~mL}$ water samples from the fish tank and plant compartments were collected at the end of the experiment and water samples were preserved in a freezer $\left(-20^{\circ} \mathrm{C}\right)$ for further analysis. Additionally, water quality was analysed. Water $\mathrm{pH}$ and water electrical conductivity were determined. The elemental composition of water was analysed by ICP OES (Thermo Scientific, Dartford, UK). The temperature and light in both compartments were monitored using HOBO Pendant ${ }^{\circledR}$ loggers (ONSET, Bourne, MA, USA). Light intensity was measured at the bottom of the compartment in lux and converted to $\mu \mathrm{mol} \mathrm{m} \mathrm{m}^{-2} \mathrm{~s}^{-1}$. Results from the background water analysis are displayed in Table 1.

Table 1. Average temperature $\left(\mathrm{T}^{\circ} \mathrm{C}\right)$, light intensity $\left(\mu \mathrm{mol} \mathrm{m}{ }^{-2} \mathrm{~s}^{-1}\right), \mathrm{pH}$, electrical conductivity $\left(\mathrm{EC}, \mathrm{mS} \mathrm{m}^{-1}\right)$, and metal elemental concentration $\left(\mathrm{mg} \mathrm{L}^{-1}\right)$ in the water samples collected from the fish and plant compartments $(n=3)$ of the studied aquaponics system.

\begin{tabular}{cccccccccccc}
\hline Compartment & $\mathbf{T}\left({ }^{\circ} \mathbf{C}\right)$ & Light & $\mathbf{p H}$ & $\mathbf{E C}$ & $\mathbf{P}$ & $\mathbf{K}$ & $\mathbf{C a}$ & $\mathbf{M g}$ & $\mathbf{N a}$ & $\mathbf{C u}$ & $\mathbf{Z n}$ \\
\hline Fish & 29.2 & 0.24 & 6.1 & 2.4 & 25 & 33.9 & 81.8 & 63.1 & 198 & 0.3 & $<0.01$ \\
Plant & 29.7 & 0.19 & 5.8 & 2.9 & 28 & 34.5 & 83.8 & 65.2 & 183 & 0.5 & $<0.01$ \\
\hline
\end{tabular}

\subsection{Prokaryote Diversity through $16 S$ rRNA Gene Sequencing}

The total genomic DNA was extracted from each of the six biofilm and water samples using a PurelinkTM microbiome DNA purification kit (Thermo Fisher Scientific, Dartford, UK) following the manufacturer's protocol. Then, the concentration and purity of DNA were measured using a NanoDropTM (Thermo Fisher Scientific, Dartford, UK) spectrophotometer. The DNA extracts were sent to Molecular Research (Shallowater, TX, USA) for bacterial 16S (515-806) amplicon diversity assays using bTEFAP ${ }^{\circledR}$ PGM/S5 (Shallowater, TX, USA). The V4 variable region of the bacterial 16S rRNA gene was amplified using 515F forward and $806 \mathrm{R}$ reverse primers with a barcode on the forward primer during 35 cycles of PCR using the HotStarTaq Plus Master Mix Kit (Qiagen, Shallowater, TX, USA). The following conditions were used: $94^{\circ} \mathrm{C}$ for $3 \mathrm{~min}$, followed by 35 cycles of $94{ }^{\circ} \mathrm{C}$ for $30 \mathrm{~s}$, $53{ }^{\circ} \mathrm{C}$ for $40 \mathrm{~s}$, and $72{ }^{\circ} \mathrm{C}$ for $1 \mathrm{~min}$; thereafter, a final elongation step at $72{ }^{\circ} \mathrm{C}$ for $5 \mathrm{~min}$ was performed. After amplification, PCR products were checked in $2 \%$ agarose gel to determine the success of amplification and the relative intensity of the bands. Samples were purified using calibrated Ampure XP beads. Pooled in equimolar ratios, the purified PCR products were sequenced using the Illumina MiSeq platform in MR DNA [23] following the manufacturer's guidelines.

The sequence data were processed using the MR DNA ribosomal and functional gene analysis pipeline and in-house built software [23]. Sequences were depleted of barcodes and primers. Sequences with ambiguous base calls or with homopolymer runs exceeding $6 \mathrm{bp}$ or short sequences $<150 \mathrm{bp}$ were removed. Sequences were denoised, and operational taxonomic units (zOTUs) were defined clustering at 3\% divergence (97\% similarity) followed by singleton sequences and chimeras removal. Final zOTUs were taxonomically classified using BLASTn against a curated database derived from RDPII and NCBI (www.ncbi.nlm.nih.gov, accessed on 1 November 2020).

\section{zOTUs Reported to Carry Phytases and Carbohydrases Enzymes}

The assigned taxa from the $16 \mathrm{~S}$ rRNA sequences obtained through the microbial diversity analysis were compared the bacterial species reported in the Pfam database (http:/ / pfam.xfam.org/, accessed on 14 September 2020) to carry different types of phytases and carbohydrases. The following protein families were selected and used in this 
analysis: beta-propeller phytase (BPP) (phytase (PF02333)), histidine acid phosphatase (HAP) (His_Phos_2 (PF00328)), Cellulase N-terminal ig-like domain (cellulase) (CelD_N (PF02927)), protein tyrosine phytases (PTP) (PTPlike_phytase (PF14566)), Beta-1,3-glucanase ( $\beta$-glucanase) (Glyco_hydro_64 (PF16483)), and Carbohydrate family 9 binding domainlike (xylanase) (CB_M91 (PF06452)). This cross-referencing was used as soft evidence for the presence and abundance of these enzymes across the samples. The bacteria screening for the studied enzymes was taken as strong evidence of the presence and abundance of these enzymes in the aquaponics system. Moreover, other inaccuracies may appear due to the use of the RDP database.

\subsection{Isolation and Identification of Bacterial Strains}

Bacterial strains were isolated from both fish and plant compartments by enrichment of $1 \mathrm{~g}$ of each biofilm sample in $20 \mathrm{~mL}$ of water from a corresponding compartment, $20 \mathrm{~mL}$ compartment water with sterile $3 \%$ wheat bran (natural source of phytate and fibres), and minimal media M9 [24]. The mixture was incubated at $37^{\circ} \mathrm{C}$ for three days. Subsequently, $100 \mu \mathrm{L}$ from each enrichment were submitted to serial dilution, inoculated on nutrient agar, and incubated at $30^{\circ} \mathrm{C}$ for one day. Pure colonies were streaked clean in fresh nutrient agar plates separately and grown for another day at $30^{\circ} \mathrm{C}$. The isolated strains were conserved in $25 \%$ glycerol-nutrient broth for subsequent assays.

Bacterial genomic DNA was extracted from all strains for further PCR assays using a HiPurA ${ }^{\text {TM }}$ Kit (HiMedia, Mumbai, India). All isolated strains positive for extracellular enzyme activities (19 strains) were identified by $16 \mathrm{~S}$ rRNA gene sequencing. For this purpose, the universal primers 27F (5'-AGAGTTTGATCCTGGCTCAG-3') and 1492R (5'-TACGGYTACCTTGTTACGACTT-3') [25] were used with a Hi-Chrom PCR Master Mix (HiMedia, Mumbai, India) according to the manufacturer's instructions. The PCR reactions were performed using $4 \mathrm{~min}$ hot start at $96^{\circ} \mathrm{C}$, followed by 30 cycles of $30 \mathrm{~s}$ at $94{ }^{\circ} \mathrm{C}, 30 \mathrm{~s}$ at $57^{\circ} \mathrm{C}$ and $1 \mathrm{~min}$ at $72{ }^{\circ} \mathrm{C}$, and a final extension step at $72{ }^{\circ} \mathrm{C}$ for $10 \mathrm{~min}$. Amplicons were purified and both forward and reverse sequenced at the Macrogen sequencing service (Macrogen Inc., Seoul, Korea). The sequences were aligned, trimmed, and compared to the closest sequence (highest ID from NCBI GenBank) and the cleaned consensus sequences were deposited in NCBI GenBank (Table 2).

\subsection{Screening for Carbohydrase-Producing Bacteria}

\subsubsection{Screening for Non-Starch Polysaccharide-Degrading Bacteria}

Bacterial isolates were inoculated onto xylanase screening agar and $\beta$-glucanase screening agar plates, which constituted of $5 \mathrm{~g} \mathrm{~L}^{-1}$ xylan (or $5 \mathrm{~g} \mathrm{~L}^{-1} \beta$-glucan for $\beta$ glucanase screening agar), $2 \mathrm{~g} \mathrm{~L}^{-1}$ yeast extract, $0.5 \mathrm{~g} \mathrm{~L}^{-1} \mathrm{NaCl}, 0.1 \mathrm{~g} \mathrm{~L}^{-1} \mathrm{CaCl}_{2}, 5 \mathrm{~g} \mathrm{~L}^{-1}$ peptone, $0.5 \mathrm{~g} \mathrm{~L}^{-1} \mathrm{MgSO}_{4} \cdot 7 \mathrm{H}_{2} \mathrm{O}$, and $20 \mathrm{~g} \mathrm{~L}^{-1}$ agar dissolved in distilled water [26] and incubated for $48 \mathrm{~h}$ at $37^{\circ} \mathrm{C}$. Then, plates were flooded with $0.1 \%$ Congo red (Sigma) solution and washed with $1 \mathrm{M} \mathrm{NaCl}$ (Sigma) solution. The presence of a clear zone (halo) indicated the isolate's extracellular $\beta$-glucanase enzymatic activity. The halo and colony diameters were recorded as semiquantitative evidence of the $\beta$-glucanase activity expressed by each strain.

For the screening of cellulase-producing bacteria, carboxymethyl cellulose $(\mathrm{CMC})$ agar medium was used, containing $5 \mathrm{~g} / \mathrm{L}$ carboxymethyl cellulose, $1 \mathrm{~g} \mathrm{~L}^{-1} \mathrm{NaNO}_{3}, 1 \mathrm{~g} \mathrm{~L}^{-1}$ $\mathrm{K}_{2} \mathrm{HPO}_{4}, 1 \mathrm{~g} \mathrm{~L}^{-1} \mathrm{KCl}, 0.5 \mathrm{~g} \mathrm{~L}^{-1} \mathrm{MgSO}_{4}, 0.5 \mathrm{~g} \mathrm{~L}^{-1}$ yeast extract, and $15 \mathrm{~g} \mathrm{~L}^{-1}$ agar dissolved in distilled water [27]. A loopful of bacterial suspension was spotted onto agar and incubated at $37^{\circ} \mathrm{C}$ for $48 \mathrm{~h}$. Similarly to the $\beta$-glucanase assays, plates were stained by flooding with $0.1 \%$ Congo red then washed using $1 \mathrm{M} \mathrm{NaCl}$ solution, and the clearance zone diameter was recorded. 


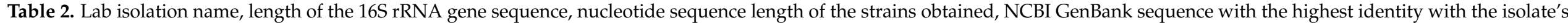
$16 \mathrm{~S}$ rRNA gene, assigned strain name, and GenBank accession number of the deposited 16S rRNA sequence.

\begin{tabular}{|c|c|c|c|c|c|c|c|}
\hline \multirow{2}{*}{ Isolation ID } & \multirow{2}{*}{ Length (bp) } & \multicolumn{4}{|c|}{ NCBI Genbank Closest Match } & \multirow{2}{*}{ Assigned Strain Name } & \multirow{2}{*}{ Accession $\mathbf{N}$} \\
\hline & & Seq. ID & Identity & Q.Cover & Species & & \\
\hline SWAM_2Aq & 1359 & MT539995.1 & $100.00 \%$ & $100 \%$ & Bacillus subtilis & Bacillus subtilis $2 \mathrm{Aq}$ & OK626679 \\
\hline SWAM_6Aq & 1318 & MT229334.1 & $98.79 \%$ & $100 \%$ & Bacillus velezensis & Bacillus velezensis $6 \mathrm{Aq}$ & OK626680 \\
\hline SWAM_8Aq & 1299 & KM922586.1 & $98.00 \%$ & $100 \%$ & Bacillus subtilis & Bacillus subtilis 8Aq & OK626682 \\
\hline SWAM_10Aq & 1317 & MF521557.1 & $93.06 \%$ & $100 \%$ & Bacillus cereus & Bacillus cereus $10 \mathrm{Aq}$ & OK626683 \\
\hline SWAM_13Aq & 1395 & MN330286.1 & $99.63 \%$ & $97 \%$ & Bacillus subtilis & Bacillus subtilis $13 \mathrm{Aq}$ & OK626684 \\
\hline SWAM_15Aq & 1405 & MK859953.1 & $99.15 \%$ & $100 \%$ & Bacillus licheniformis & Bacillus licheniformis $15 \mathrm{Aq}$ & OK626685 \\
\hline SWAM_17Aq & 1422 & MH005066.1 & $91.82 \%$ & $99 \%$ & Bacillus infantis & Bacillus sp. 17Aq & OK626687 \\
\hline SWAM_18Aq & 1416 & MT122066.1 & $99.36 \%$ & $100 \%$ & Bacillus tequilensis & Bacillus tequilensis $18 \mathrm{Aq}$ & OK626688 \\
\hline SWAM_21Aq & 1446 & СР035288.1 & $93.05 \%$ & $99 \%$ & Staphylococcus epidermidis & Staphylococcus sp. $21 \mathrm{Aq}$ & OK626689 \\
\hline SWAM_22Aq & 1347 & LS974830.1 & $93.87 \%$ & $100 \%$ & Rossellomorea marisflavi & Rossellomorea sp. $22 \mathrm{Aq}$ & OK626690 \\
\hline SWAM_23Aq & 1380 & MN704425.1 & $98.04 \%$ & $99 \%$ & Bacillus stercoris & Bacillus subtilis $23 \mathrm{Aq}$ & OK626691 \\
\hline SWAM_26Aq & 1414 & MT111029.1 & $98.46 \%$ & $100 \%$ & Bacillus subtilis & Bacillus tequilensis $26 \mathrm{Aq}$ & OK626692 \\
\hline SWAM_28Aq & 1427 & МT326233.1 & $98.95 \%$ & $100 \%$ & Bacillus licheniformis & Bacillus licheniformis 28Aq & OK626693 \\
\hline SWAM_29Aq & 1371 & MT611946.1 & $98.53 \%$ & $100 \%$ & Bacillus cereus & Bacillus cereus $29 \mathrm{Aq}$ & OK626694 \\
\hline SWAM_33Aq & 1433 & СР053934.1 & $99.02 \%$ & $100 \%$ & Bacillus thuringiensis & Bacillus thuringiensis $33 \mathrm{Aq}$ & OK626695 \\
\hline SWAM_37Aq & 1423 & MK942526.1 & $89.88 \%$ & $100 \%$ & Bacillus subtilis & Bacillus sp. 37Aq & OK626697 \\
\hline
\end{tabular}




\subsubsection{Screening for Starch-Degrading Bacteria}

Similarly to the cellulases and $\beta$-glucanases assays, amylase screening agar plates were used to assess the ability of the bacteria strains to produce extracellular amylases [28]. The amylase screening agar medium contained $10 \mathrm{~g}$ of starch, $2 \mathrm{~g}$ of yeast extract, $5 \mathrm{~g}$ of peptone, $0.5 \mathrm{~g}$ of $\mathrm{MgSO} 4,0.5 \mathrm{~g}$ of $\mathrm{NaCl}, 0.15 \mathrm{~g}$ of $\mathrm{CaCl} 2,2 \mathrm{~g}$ agar, and $1 \mathrm{~L}$ of water. The plates were incubated for $48 \mathrm{~h}$ at $37^{\circ} \mathrm{C}$. Then, they were flooded with Gram's iodine solution, and the clearance zones $(\mathrm{mm})$ and diameter of colonies $(\mathrm{mm})$ were recorded in triplicate.

\subsection{Screening for Phytase-Producing Bacteria}

Bacterial isolates were screened for phytase production using Phytase Screening Medium (PSM) (Demirkan et al., 2014) and M9 Minimal medium with phytate. The M9 broth minimal medium with phytate contained $0.4 \%$ Na-phytate (sterile filtered), $0.1 \%$ $\mathrm{NH}_{4} \mathrm{Cl}, 0.012 \% \mathrm{MgSO} 4$, and $0.00147 \% \mathrm{CaCl}_{2}$. The PSM medium consisted of $20 \mathrm{~g} \mathrm{~L}^{-1}$ Glucose, $2 \mathrm{~g} \mathrm{~L}^{-1} \mathrm{CaCl}_{2}, 5 \mathrm{~g} \mathrm{~L}^{-1} \mathrm{NH}_{4} \mathrm{NO}_{3}, 0.5 \mathrm{~g} \mathrm{~L}^{-1} \mathrm{MgSO}_{4}, 0.5 \mathrm{~g} \mathrm{~L}^{-1} \mathrm{KCl}, 0.01 \mathrm{~g} \mathrm{~L}^{-1}$ $\mathrm{FeSO}_{4}$, and $4 \mathrm{~g} \mathrm{~L}^{-1} \mathrm{Na}$-phytate (sterile filtered). Isolates were inoculated in both media and incubated at $37^{\circ} \mathrm{C}$ for 14 days. Subsamples were collected daily and analysed for the soluble inorganic phosphate concentration using the malachite green method [29]. The isolates that showed a significant increase in the extracellular phosphorus concentration were reassayed in the corresponding medium for another 14 days at $37^{\circ} \mathrm{C}$ for confirmation of the results. The bacterial growth was also measured daily by OD at $600 \mathrm{~nm}$. The uninoculated corresponding sterile media was used as a control.

\subsection{Detection of Phytase Genes by PCR Amplification Using Degenerate Primers}

The presence of phytase genes was examined using PCR assays using degenerate primers of two different classes (BPP and PTP). This assay was performed for both the environmental genomic DNA extracted from biofilm/water samples and the genomic DNA extracted from the bacterial isolates. For BPP phytases, two different primer pairs were used according to Huang et al. (2009) [30]: BPP-F (5'-GACGCAGCCGA YGAYCCNGCNITNTGG-3') and BPP-R (5'-CAGGSCGCANRTCIACRTTRTT-3'). The PCR conditions were: $4 \mathrm{~min}$ hot start at $95{ }^{\circ} \mathrm{C}$, followed by eight cycles of $95{ }^{\circ} \mathrm{C}$ for $30 \mathrm{~s}, 57^{\circ} \mathrm{C}$ (decreasing by $1^{\circ} \mathrm{C}$ after each cycle) for $30 \mathrm{~s}$, and $72{ }^{\circ} \mathrm{C}$ for $30 \mathrm{~s}$, followed by 27 cycles of $95{ }^{\circ} \mathrm{C}$ for $30 \mathrm{~s}, 48^{\circ} \mathrm{C}$ for $30 \mathrm{~s}$, and $72{ }^{\circ} \mathrm{C}$ for $30 \mathrm{~s}$, and then a final extension at $72{ }^{\circ} \mathrm{C}$ for $5 \mathrm{~min}$. For the second BPP primer pair, DP1 (5'-GAY GCI GCI GAY GAY CCI GC-3') and DP2 (5'-TCR TAY TGY TCR AAY TCIC-3') primers were used according to Tye et al. (2002) [31]. Amplification was carried out for 30 cycles of $94{ }^{\circ} \mathrm{C}$ for $45 \mathrm{~s}, 50{ }^{\circ} \mathrm{C}$ for $45 \mathrm{~s}$, and $72{ }^{\circ} \mathrm{C}$ for $1 \mathrm{~min}$. For the PTP phytase gene amplification, the primers CPhy-F (5'-GTGGACCTRCGRMARGARWCICA-3') and Cphy-R (5'- GTCCGACCATTGCCTGCYTCRCARTGRAMRTGIADCCA-3') were used according to Huang et al. [32]. The PCR conditions were: $95^{\circ} \mathrm{C}$ for $4 \mathrm{~min}, 10$ cycles of $94{ }^{\circ} \mathrm{C}$ for $30 \mathrm{~s}$, $58{ }^{\circ} \mathrm{C}$ for $30 \mathrm{~s}$ (decreasing $0.5^{\circ} \mathrm{C}$ for each cycle), and $72{ }^{\circ} \mathrm{C}$ for $30 \mathrm{~s}$, followed by 27 cycles of $94{ }^{\circ} \mathrm{C}$ for $30 \mathrm{~s}, 52{ }^{\circ} \mathrm{C}$ for $30 \mathrm{~s}$, and $72{ }^{\circ} \mathrm{C}$ for $30 \mathrm{~s}$, and a final extension step at $72{ }^{\circ} \mathrm{C}$ for $10 \mathrm{~min}$.

\subsection{Statistical Analyses}

The data were analysed using one-way ANOVA and Tukey's test, $p \leq 0.05$ was used as the significance level. Data calculations, manipulation, average, standard deviation, and correlation analysis were performed using Microsoft Office Excel 2016. Krona [33] was used to build HTML interactive hierarchical microbial diversity graphics, allowing for the visualisation of changes in the microbial community composition. PAST4 [34] was used for calculating the microbial diversity indexes, and JMP13 statistical software was used for ANOVA and PCA interpretation of the effect of the treatments on the microbial parameters. Graphia 2.0 was used to build a correlation network of OUTs with Pearson's correlation coefficients above 0.95 [35], clustered by Markov Cluster Algorithm (MCL, granularity 1.1). 


\section{Results}

\subsection{S rRNA Diversity of Bacterial Communities in Fish and Plant Compartments}

Due to the high data variability among replicates from the three studied independent Aquaponics systems, the bacteria community composition was not statistically different between fish and plant compartments. In total, 149,197 bacterial sequences and 1655 zOTUs were obtained from the fish compartments samples and 115,182 sequences and 1424 zOTUs from samples that originated from plant compartments. The Shannon diversity index $(\mathrm{H})$, Dominance (D), and Evenness (EH) were very similar for fish $(n=3)$, plant $(n=3)$, and fish + plant compartments $(n=6)$ as shown in Table 3. This was observed both when the analysis was performed using the sum of the number of sequences of zOTUs from individual samples, and also when averaged $(\bar{x})$ from individual samples. It is noteworthy that even though the diversity indexes were not different between fish and plant compartments, 527 zOTUs uniquely occurred in plant compartments ( $27 \%$ of total zOTUs), and 296 zOTUs were only found in fish compartments ( $15 \%$ of total zOTUs). This is evidence that these two environments are very different in their bacterial community composition.

Table 3. Shannon diversity index (H), Dominance (D), and Evenness (EH) of total prokaryotic operational taxonomic units (zOTUs) for three independent demonstrative aquaponics systems. Samples were grouped by fish $(n=3)$, plant $(n=3)$, and fish + plant compartments $(n=6)$ followed by average $(\bar{x})$ and standard error $(\sigma \bar{x})$. Analysis was performed using PAST4 software.

\begin{tabular}{cccccccccc}
\hline & Fish & $\overline{\mathbf{x}}$ & $\boldsymbol{\sigma} \overline{\mathbf{x}}$ & Plant & $\overline{\mathbf{x}}$ & $\boldsymbol{\sigma} \overline{\mathbf{x}}$ & Fish + Plant & $\overline{\mathbf{x}}$ & $\boldsymbol{\sigma} \overline{\mathbf{x}}$ \\
\hline Shannon H & 5.96 & 5.17 & 0.21 & 5.90 & 5.23 & 0.18 & 6.24 & 5.20 & 0.12 \\
Dominance D & 0.01 & 0.01 & 0.00 & 0.01 & 0.01 & 0.00 & 0.00 & 0.01 & 0.00 \\
Evenness E H & 0.24 & 0.25 & 0.06 & 0.26 & 0.27 & 0.02 & 0.26 & 0.26 & 0.03 \\
\hline
\end{tabular}

Only a small proportion of Archaea (0.1 to $0.2 \%$ ) was present in the samples. In fish tanks, $82 \%$ of Archaea belonged to phyla Thaumarchaeota and $18 \%$ to Euryarchaeota (class Thermoplasmata). The dominant genera included Candidatus Nitrososphaera, Cenarchaeum, and Methanomassiliicoccus. In the plant compartment samples, all Archaea belonged to the Thaumarchaeota phylum with dominant genera Nitrososphaera, Candidatus Nitrososphaera, and Candidatus Nitrosoarchaeum.

Bacterial communities were dominated by Proteobacteria and Bacteroidetes phyla (Figure 1). The Proteobacteria phylum accounted for $53 \%$ of the total sequences in the fish tanks and $49 \%$ of the total reads in the plant compartment. The Bacteroidetes phylum was more abundant in the fish compartment $(24 \%)$ than in the plant compartment $(15 \%)$. Among Proteobacteria, Alphaproteobacteria was the most dominant class (23-24\%, Figure 1), followed by Gammaproteobacteria, Betaproteobacteria, and Deltaproteobacteria. The phylum Bacteroidetes was largely represented by the Sphingobacteriia, Flavobacteriia, and Cytophagia classes (Figure 1). The phyla Firmicutes, Nitrospirae, Planctomycetes, and Actinobacteria were less abundant (Figure 1). Notably, the relative abundance of the phyla Nitrospirae, Planctomycetes Verrucomicrobia, and Actinobacteria was two-fold higher in the plant compartments than in fish compartments. Similarly, the classes Bacilli, Clostridia, Fusobacteria, and Chloroflexi were present in both compartments but were around two-folds more abundant in the plant than in the fish compartment. 

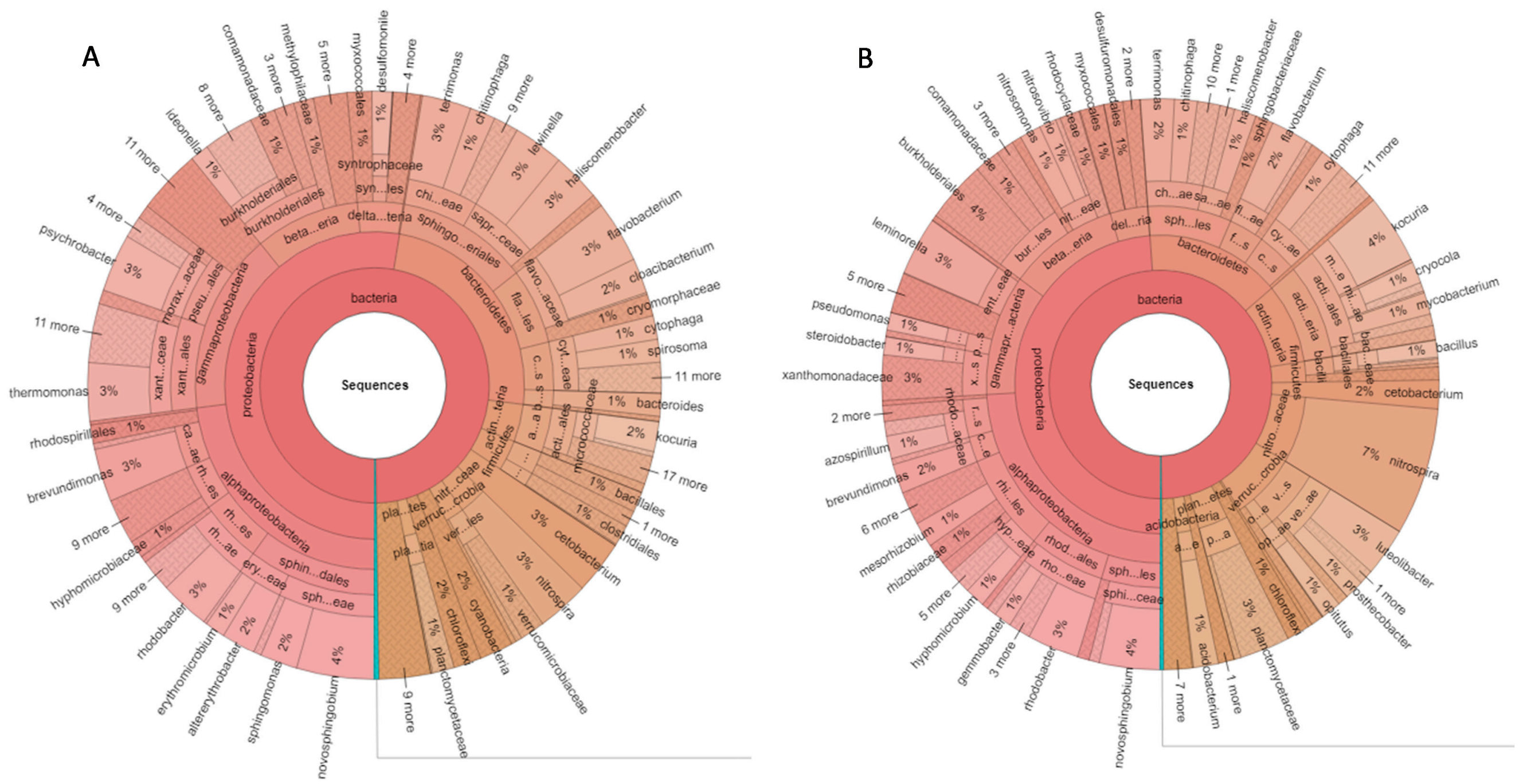

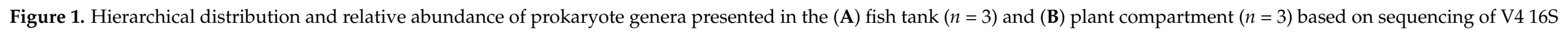
rRNA gene diversity analysis. 


\subsection{Multivariate Correlation Network Clustering of Bacteria Taxa}

The correlation network clustering of bacteria zOTUs using Markov Cluster Algorithm (MCL, granularity 1.1) showed an outcome of six well-defined clusters (Figure 2). Most of the prokaryote taxa were represented in clusters 1 and 2. Clusters 1 and 3 were 'central' clusters (linking to all other clusters), and cluster 5 was the most detached among the six clusters, connected only with clusters 1 and 3 . Cluster 1 was very diverse, represented mainly by Sphingobacteriia, Erysipelotrichia, and Bacteroidetes classes. In addition, cluster 1 was extremely rich with species that were reported to carry BPP phytase enzyme and different carbohydrases, such as xylanase, $\beta$-glucanase, and cellulases (see Section 3.3). Cluster 3 was dominated by Euryarchaeota, Oscillatoriophycideae, Fibrobacteres, Holophagae, and Thermoplasmata phyla. Cluster 5 largely contains microbes belonging to Acidobacteria and Chloroflexi phyla. Moreover, most zOTUs reported to harbour PTP phytase genes were represented by cluster 2 , which was most abundant in plant compartments. The zOTUs most representative from fish compartments (the highest in abundance) were predominantly contained in clusters 1,3 , and 5 , while the zOTUs' most representative plant compartments belonged primarily to clusters 2,4 , and 6 .

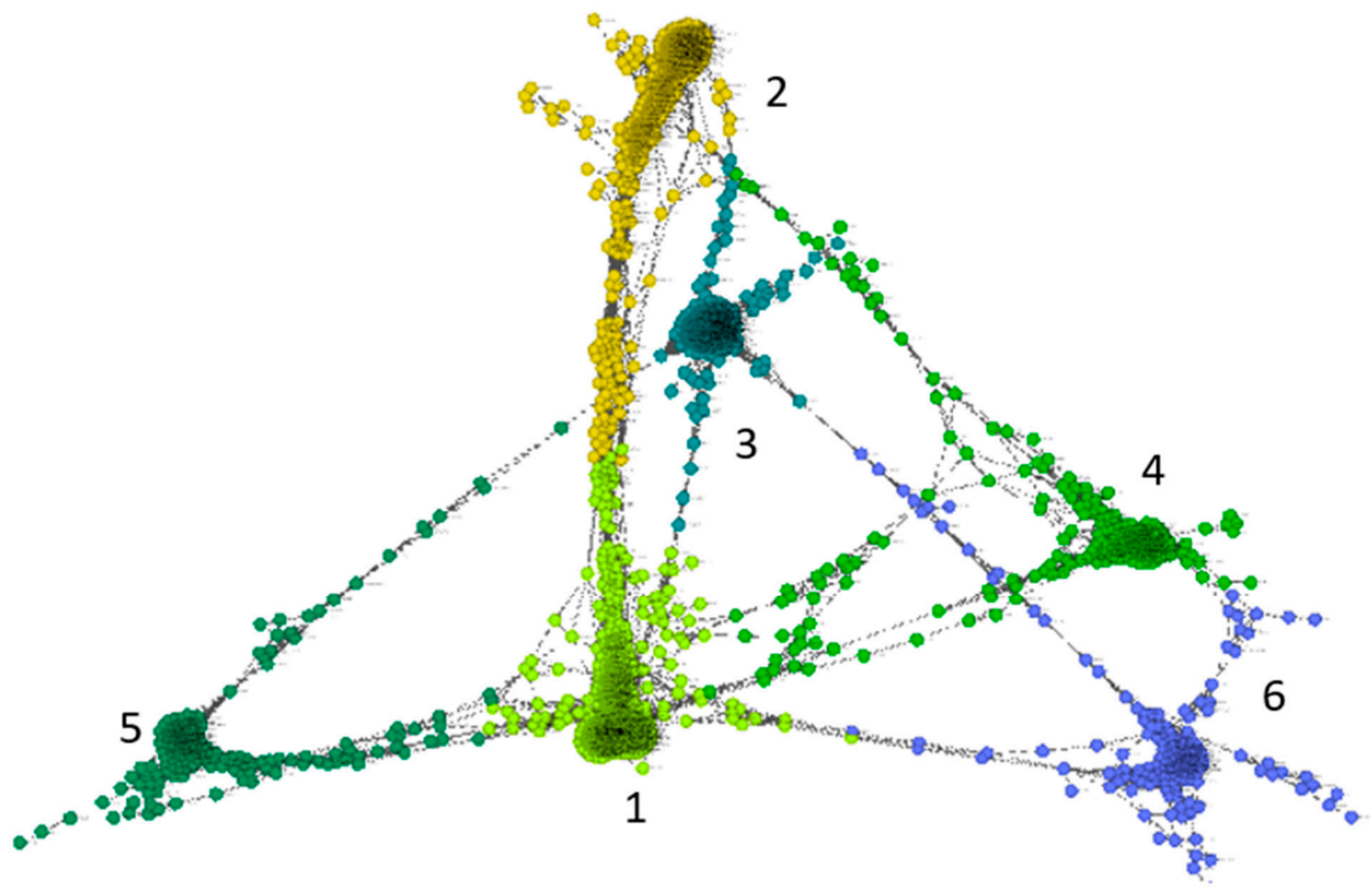

Figure 2. Correlation network clustering of operation taxonomic units (zOTUs) present in fish and plant compartments of an aquaponics system. Figure generated using Graphia software ( $r \geq 0.95)$ and OUT data from V4 16S rRNA. Fish compartment zOTUs were best represented by clusters 1,3 , and 5 , whereas plant compartment zOTUs were best represented by clusters 2,4 , and 6 .

\subsection{Diversity and Abundance of Microbes Reported to Carry Putative Phytases and Carbohydrase Enzyme Genes}

The outcome zOTUs from the V4 16 rRNA diversity analysis were cross-compared to the bacterial species reported to harbour phytase or carbohydrase genes in the Pfam database (http://pfam.xfam.org/, accessed on 14 September 2020, Table 4). Given the currently available knowledge, this analysis represents the abundance and diversity of bacteria potentially carrying the putative genes for the studied enzymes (here deemed 'potential producers'). Therefore, these data must be taken as soft evidence and only as 
an attempt to extract valuable information from the $16 \mathrm{~S}$ diversity analysis pertaining to the scope of the objectives of this study. Besides reporting the total number of zOTUs of 'potential enzyme producers', Table 3 also illustrates their relative abundance and the average and standard error per sample. The high standard error observed highlights that the high variability of the microbial communities between independent aquaponics systems prevents definitive conclusions being drawn when comparing fish and plant compartments. Among the observed zOTUs in the aquaponics system used, the relative abundance of zOTUs from potential carbohydrases producers was 2.8-fold higher than the ones reported to carry phytase putative genes (Table $323 \%$ carbohydrases and $8 \%$ phytases). The fish tank samples showed a higher relative abundance of zOTUs from potential carbohydrase producers compared to the samples from the plant compartments $(26 \%$ and $19 \%$, correspondingly). The number of putative phytase sequences was similar in both compartments. The relative abundance of zOUTs potentially carrying BPP phytase genes was around $6 \%$ for both compartments, twice the relative abundance observed for HAP phytases (3\% of sequences). Bacterial zOTUs potentially harbouring PTP putative phytase genes were less abundant than for other types of phytases, corresponding to $<1 \%$ of the reads in both compartments. The number of zOTUs of bacteria reported to carry putative genes of different types of carbohydrases, such as cellulase, $\beta$-glucanase, and xylanase, were more abundant in the fish compartment compared to the plant compartment. Among carbohydrases, the relative abundance of bacterial zOTUs of potential cellulase producers was more abundant in plant compartments (18\%) than in fish compartments $(23 \%)$.

Table 4. Number of total operational taxonomic units (zOTUs) of fish $(n=3)$, plant $(n=3)$ and fish+plant compartments $(n=6)$ in three independent demonstrative aquaponics systems, their relative abundance with respect the total amount of sequences $(\%)$, the average of the number of OTUs $(\bar{x})$, and standard error $(\sigma \bar{x})$ of prokaryotes previously reported to carry putative phytases ( $\beta$-propeller BPP (PF02333); Histidine acid phytases HAP(PF00328); protein tyrosine phytases PTP (PF14566)) and Carbohydrases putative genes (B-glucanase (PF16483); Xylanase (PF06452); Cellulases (PF02927)). Analysis was performed by comparing the zOTUs $16 \mathrm{~S}$ rRNA diversity analysis with a curated database extracted from PFAM (http:/ / pfam.xfam.org/, accessed on 14 September 2020).

\begin{tabular}{|c|c|c|c|c|c|c|c|c|c|c|c|c|}
\hline & Fish & $\% *$ & $\overline{\mathbf{X}}$ & $\sigma \overline{\mathbf{x}}$ & Plant & $\% *$ & $\overline{\mathbf{x}}$ & $\sigma \overline{\mathbf{x}}$ & Fish + Plant & $\% *$ & $\overline{\mathbf{x}}$ & $\sigma \overline{\mathbf{X}}$ \\
\hline$A l l$ & 1655 & 100 & 794 & 245 & 1424 & 100 & 733 & 188 & 1951 & 100 & 763 & 139 \\
\hline$B P P$ & 76 & 6 & 39 & 13 & 68 & 5 & 33 & 12 & 90 & 6 & 36 & 8 \\
\hline$H A P$ & 46 & 3 & 21 & 8 & 31 & 3 & 17 & 4 & 54 & 3 & 19 & 4 \\
\hline PTP & 6 & $<1$ & 2 & 2 & 10 & $<1$ & 3 & 2 & 12 & $<1$ & 3 & 1 \\
\hline All phytases & 98 & 9 & 50 & 17 & 87 & 8 & 41 & 14 & 120 & 8 & 46 & 10 \\
\hline B-glucanase & 28 & 2 & 15 & 3 & 23 & 1 & 9 & 4 & 31 & 1 & 12 & 3 \\
\hline Xylanase & 108 & 6 & 55 & 18 & 77 & 4 & 34 & 12 & 117 & 5 & 44 & 11 \\
\hline Cellulases & 220 & 18 & 116 & 32 & 220 & 23 & 116 & 32 & 250 & 17 & 116 & 20 \\
\hline All carbohydrases & 232 & 26 & 120 & 34 & 199 & 19 & 103 & 21 & 266 & 23 & 112 & 18 \\
\hline
\end{tabular}

\subsection{Phytase-, Xylanase-, $\beta$-glucanase-, Cellulase-, and Amylase-Producing Bacterial Isolates}

Thirty-eight bacterial isolates were obtained from the fish tanks and plant compartments of the outdoor aquaponics system, and among them, 19 produced at least one of the extracellular enzyme activities looked for (Table 5). Only the strains with enzyme activities were identified by $16 \mathrm{~S}$ sequencing. Most of them belonged to the Bacillus genus. Five strains (2Aq, 7Aq, 8Aq, 13Aq, 26Aq) were identified as Bacillus subtilis, two as Bacillus cereus, and another two as Bacillus tequilensis. Besides the Bacillus genus, Staphylococcus and Rossellomorea were also found (Table 2). The four isolates B. subtilis $2 \mathrm{Aq}$ and $7 \mathrm{Aq}$, B. velezensis $6 \mathrm{Aq}$, and B. tequilensis $18 \mathrm{Aq}$ were capable of producing xylanase, $\beta$-glucanase, cellulase, and amylase (Table 5). The carbohydrases looked for were differentially expressed by different isolates, based on the different diameters of the clear zone on specific agar minimal media. Moreover, B. subtilis $8 \mathrm{Aq}$ and $13 \mathrm{Aq}$ showed the ability to produce $\beta$-glucanase, cellulase, and amylase but not xylanase. On the other hand, three isolates Bacillus sp. 16Aq, B. subtilis $2 \mathrm{Aq}$, and B. licheniformis $28 \mathrm{Aq}$ produced only cellulases, whereas B. cereus $10 \mathrm{Aq}$ 
and Rossellomorea sp. 36Aq could produce the only amylase. In total, 7, 8, 14, and 11 isolates could secrete extracellular xylanase, $\beta$-glucanase, cellulase, and amylase, respectively.

Table 5. Bacterial isolates from the fish and plant compartments of the aquaponics system with the ability to produce extracellular phytase (increase extracellular phosphate concentration in PSM medium), xylanase (XSA, xylanase screening agar clear zone in $\mathrm{mm}$ ), $\beta$-glucanase (BSA, $\beta$-glucanase screening agar clear zone in $\mathrm{mm}$ ), cellulase (CSA, cellulase screening agar clear zone in $\mathrm{mm}$ ), and amylase (ASA, amylase screening agar clear zone in $\mathrm{mm}$ ). ' + ' indicates significant extracellular enzyme activity and '-' no extracellular enzyme activity was detected.

\begin{tabular}{|c|c|c|c|c|c|c|}
\hline Source & Strain & Phy & XSA & BSA & CSA & ASA \\
\hline Fish & Bacillus subtilis $2 \mathrm{Aq}$ & - & 24 & 14 & 25 & 26 \\
\hline Fish & Bacillus velezensis $6 \mathrm{Aq}$ & - & 26 & 24 & 16 & 18 \\
\hline Fish & Bacillus subtilis 7Aq & - & 25 & 27 & 18 & 14 \\
\hline Fish & Bacillus subtilis 8Aq & - & - & 26 & 20 & 14 \\
\hline Fish & Bacillus cereus $10 \mathrm{Aq}$ & - & - & - & - & 20 \\
\hline Fish & Bacillus subtilis $13 \mathrm{Aq}$ & - & - & 49 & 27 & 20 \\
\hline Fish & Bacillus licheniformis $15 \mathrm{Aq}$ & - & 26 & - & 15 & - \\
\hline Fish & Bacillus sp. $16 \mathrm{Aq}$ & - & - & - & 12 & - \\
\hline Plant & Bacillus sp. 17Aq & - & - & 33 & - & - \\
\hline Plant & Bacillus tequilensis $18 \mathrm{Aq}$ & - & 23 & 46 & 26 & 22 \\
\hline Plant & Staphylococcus sp. $21 \mathrm{Aq}$ & + & - & - & - & - \\
\hline Plant & Rossellomorea sp. $22 \mathrm{Aq}$ & - & - & - & 25 & - \\
\hline Plant & Bacillus subtilis $23 \mathrm{Aq}^{1}$ & - & 16 & 25 & - & - \\
\hline Plant & Bacillus tequilensis $26 \mathrm{Aq}$ & - & 36 & - & 25 & 30 \\
\hline Plant & Bacillus licheniformis $28 \mathrm{Aq}$ & - & - & - & 13 & - \\
\hline Plant & Bacillus cereus $29 \mathrm{Aq}$ & - & - & - & 16 & - \\
\hline Plant & Bacillus thuringiensis $33 \mathrm{Aq}$ & - & - & - & 16 & 21 \\
\hline Plant & Rossellomorea sp. 36Aq & + & - & - & - & 13 \\
\hline Plant & Bacillus sp. 37Aq & - & - & - & 15 & 10 \\
\hline
\end{tabular}

All strains grown in phytate-supplemented M9 medium did not show any release of phosphorus. However, when cultured in PSM medium for one week, seven different strains were capable of increasing the phosphorus concentration in the growth medium. Nevertheless, the initial assays were somewhat ambiguous, and these seven isolates that initially showed a significant increase in phosphorus concentrations were re-assayed for another 14 days of cultivation. Only two phytase-producing bacteria were confirmed: Staphylococcus sp. 21Aq and Rossellomorea sp. 36Aq were able to consistently increase the extracellular concentration of phosphorus after eight days of cultivation in PSM medium. These isolates exhibited high phosphorus release capabilities, sustaining over $20 \mathrm{mg}$ of $\mathrm{P} \mathrm{L}^{-1}$ from days 8 to day 14 of cultivation (Figure 3). To confirm the presence of phytase genes, different phytase degenerate primers BPP (for BPP), DP (for BPP), and Cphy (for PTP) were used. Results showed that these strains showed positive amplification of the BPP primers, thus indicating that these bacteria very likely produce $\beta$-propeller phytases. 


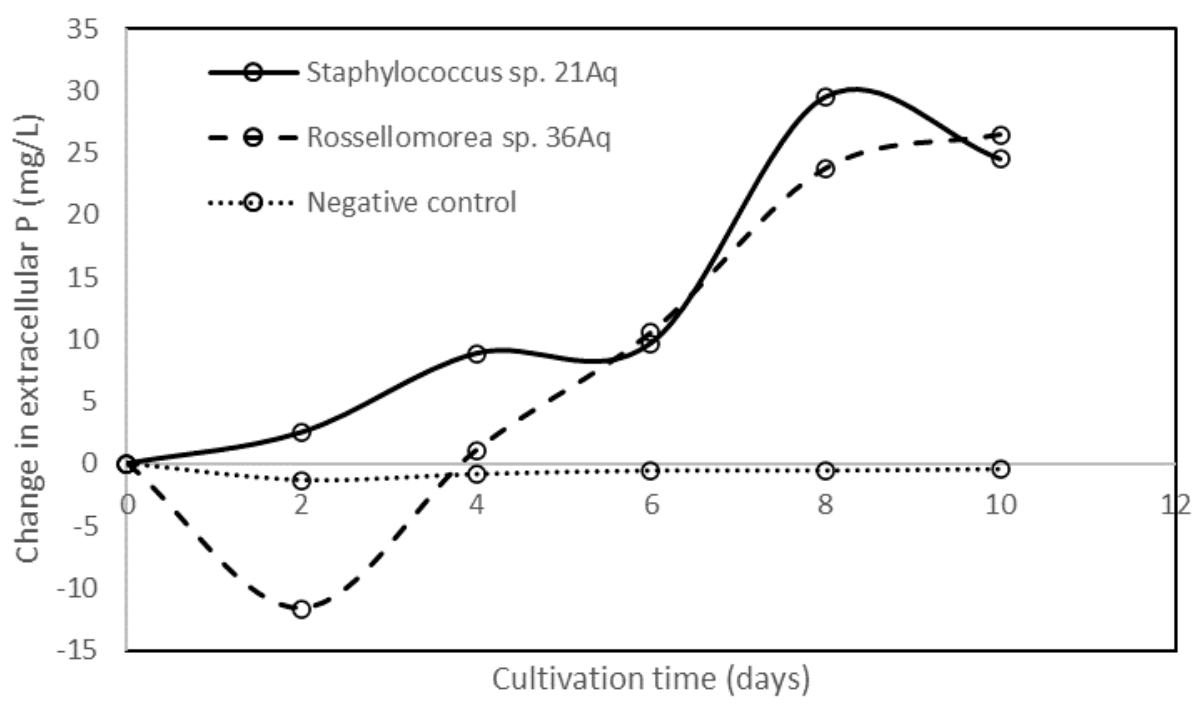

Figure 3. Change in the phosphorus concentration $\left(\mathrm{mg} \mathrm{L}^{-1}\right)$ in PSM medium (with respect to uninoculated control) after inoculation with Staphylococcus sp. 21Aq or Rossellomorea sp. 36Aq strains. The Bacillus sp. 37Aq strain with no extracellular phytate hydrolysis ability was used as the negative control illustration.

\section{Discussion}

Aquaponics are commonly proposed efficient recirculating aquatic systems that combine the production of aquatic organisms (fish) and plants with the re-use of water [11]. In order to function properly, aquaponics systems rely on proper organic matter mineralisation and nutrient cycling. These processes are heavily reliant on water and microbial biofilms. Thus, it is necessary to study microbes and their enzymes associated with aquapoincs systems. Nitrogen transformations are carried out by both aerobic and anaerobic heterotrophic microorganisms [36]. Various microniches exist within recirculating aquaponics systems that promote the growth of specific microbial communities, which play a role in mineralising organic wastes [37]. In aquaponics, both heterotrophic and autotrophic bacteria are present. Autotrophic bacteria may be chemolithotrophic, obtaining energy through the oxidation of iron, sulphur, or inorganic nitrogen. Heterotrophic bacteria use undigested organic matter from fish faeces as a source of energy and carbon $[37,38]$ and are responsible for proteolysis and sulfate reduction [38]. Eutrophic bacterial biomass increases with the increase of suspended and dissolved organic matter [39].

Most microbial studies in aquaponics systems are based on culture-dependent techniques, and the number of studies that utilise next-generation DNA sequencing techniques are limited [8]. In this study, the V4 16S rDNA diversity analysis together with culture techniques showed highly variable and diverse bacterial communities. We expected different communities in fish and plant compartments because various microniches exist within recirculating aquaponics systems that promote the growth of specific microbial communities, which play a role in mineralising organic wastes [37]. However, the link between fish and plant compartments to specific bacterial communities was not strongly demonstrated due to high differences in the relative abundance of zOTUs among replicates of independent aquaponics systems. While measured environmental parameters, like temperature, light, and metal elemental concentration, were similar between replicated systems, other environmental factors could be responsible for the high variability in the relative abundance of zOTUs.

In this study, Proteobacteria was the most dominant phylum in both fish and plant compartments. Alphaproteobacteria, Flavobacteria, Sphingobacteriia, and Cytophagi were the most abundant classes observed. Similarly, in another study of bacterial communities by $16 \mathrm{~S}$ rRNA sequencing of eight aquaponics and aquaculture systems, it was demonstrated that Proteobacteria and Bacteroidetes were the most abundant phyla [40]. Classes 
Alphaproteobacteria, Gammaproteobacteria, Actinobacteria, Bacteroidetes, Planctomycete, Bacilli, Nitrospirae, Betaproteobacteria, Nitrosomonas, and Sphingobacteria have been reported as the most common ones found in freshwater aquaponics systems [8]. The differences between classes of bacteria in different studies could be explained by the type of aquatic organisms grown in the aquaponics system. For example, Sugita et al. [38] reported that Alphaproteobacteria and Betaproteobacteria were the most abundant phyla in freshwater recirculating aquaponics when using common carp (Cyprinus carpio) species. When goldfish (Carrassius auratus) was used, the bacterial community was more diverse and included Planctomycetacia, Bacilli, Actinobacteria, Planctomycetacia, and Gammaproteobacteria bacterial groups.

In aquaponics, both heterotrophic and autotrophic bacteria are present. Autotrophic bacteria may be chemolithotrophic and obtain energy through the oxidation of iron, sulphur, or inorganic nitrogen. Heterotrophic bacteria use undigested organic matter from fish faeces as a source of energy and carbon $[37,38]$ and are responsible for proteolysis and sulfate reduction [38]. Heterotrophic bacteria in aquaponics systems that can produce extracellular hydrolytic enzymes may possibly be of biotechnological interest for feedenzyme supplement applications. In this study, 38 bacterial strains were isolated; most were identified to belong to the Bacillus genus. Even though the V4 16S rRNA diversity analysis (Figure 1) revealed that Flavobacterium, Haliscomenobacter, Nitrospira, Thermomonas, and Novosphingobium were highly abundant genera, these were not found among our isolates. However, the genera Flavobacterium and Novosphingobium were previously reported to carry phytases, and Flavobacterium, Haliscomenobacter, and Cetobacterium were reported to carry carbohydrases putative genes in the PFAM database (http:/ / pfam. xfam.org/, accessed on 14 September 2020). Nishioka et al. (2016) [41] reported that the use of selective culture media is important for the effective isolation of Flavobacterium spp. This might explain the failure in our study to isolate Flavobacterium in our study. Further work is needed, testing different minimal media and culture conditions for the isolation of targeted strains of interest that can be spotted through 16S rRNA diversity assays.

While screening for the isolates' capability of secreting fibre and starch-degrading enzymes, four Bacillus isolates showed the ability for simultaneously producing xylanase, $\beta$-glucanase, cellulase, and amylase (Table 5). These bacteria may be of high interest for enzyme production and biotechnological applications due to their high growth rate, their ability to harbour multi-enzyme complexes, and their steadiness in extreme conditions [42] Bacillus strains are usually able to utilise different complex mixtures of organic material by producing numerous extracellular enzymes that hydrolyse polysaccharides [42]. In this study, seven Bacilli strains were able to secrete xylanases, the least common carbohydrase detected. Different studies have cloned and characterised xylanases from B. subtilis [43], and many other Bacillus are known to harbour xylanases [44]. In this study, five B. subtilis were isolated, but only three (2Aq, 7Aq, and 23Aq) were positive for xylanase activity, whereas two isolates $8 \mathrm{Aq}$ and $13 \mathrm{Aq}$ were negative for this activity. This shows that species identification may not be a good predictor of their ability to express any given enzyme; these traits may only be traceable for a given strain and not evenly distributed for all strains within a given species. Shakir et al. [45] reported a B. licheniformis-producing xylanase, and Singh et al. [46] described xylanase production from B. pumilus. Among the isolates obtained in this study, the other Bacilli expressing extracellular xylanase activity in agar media were $B$. subtilis $2 \mathrm{Aq}$, B. velezensis $6 \mathrm{Aq}$, B. licheniformis $15 \mathrm{Aq}$, B. subtilis $23 \mathrm{Aq}$, and B. tequilensis $18 \mathrm{Aq}$ and $26 \mathrm{Aq}$.

In our study, eight of the isolates obtained could produce extracellular $\beta$-glucanase activity. Bacillus strains are known $\beta-1,3-1,4$-glucanases sources, and previously their enzymes have been characterised from different donor species, such as $B$. subtilis, B. licheniformis, B. brevis, B. halodurans, and B. circulans [47]. Furthermore, 14 Bacilli isolates showed the ability to produce cellulase. The production of cellulases was previously detected from several Bacilli, such as B. subtilis, B. cereus, and B. circulans [48]. Bacilli commonly produce amylases, and B. firmus [49] and B. subtilis [50] are among the most common reported 
amylase-producing bacteria. Among the Bacilli bacterial isolates in this study, 11 isolates were able to secrete amylase, although this trait is considered a widespread trait in aquatic environments and of overall lower biotechnological interest. Many enzymes used in the industrial sector are produced by Bacilli, especially by B. amyloliquefaciens, B. subtilis, and $B$. licheniformis, because they are safe to handle, produce high enzyme yields, and have good fermentation properties [51]. Isolation of similar species in our study suggested that bacteria in aquaponics systems could be a good source of novel industrial enzymes.

The detection of phytase genes (PCR amplification using degenerate primers from environmental DNA extracted from the two compartments) was only positive when using BPP primers, suggesting that the $\beta$-propeller phytase class is widespread and of high ecological importance in the studied aquaponics systems. Previous studies of bacteria in aquaponics systems mostly focused on the presence of pathogens and chemo-lithoautotrophic nitrifiers [10]. This study, for the first time, showed the presence of microbes with $\beta$-propeller phytase, which suggests that bacteria, such as Bacilli, can increase the extracellular phosphorus concentration. Extracellualr phosphorus is necessary for plant mineralization and growth in aquaponics systems [52].

Cheng and Lim [53] reported that among the four phytases classes, only $\beta$-propeller was identified in aquatic environments. Similarly, Lim et al. (2007) [54] showed that HAP and PTP phytases are uncommon in aquatic bacteria, but $\beta$-propeller phytases play a central role in phytate-phosphorus cycling in aquatic habitats. $\beta$-propeller phytases are typically active in neutral-alkaline $\mathrm{pHs}$, use calcium as a cofactor, and are typically produced by a wide range of Bacilli $[55,56]$. Curiously, although most of the isolates obtained were from the Bacillus genus, the only two isolates with positive phytase production belonged to Staphylococcus and Rossellomorea genus. Phytase activity is arguably more challenging to detect than carbohydrases, because: (a) phytases are often exclusively intracellularly expressed in bacteria; (b) their expression is often triggered by different environmental stresses (P deficiency, anaerobioses, etc.); and (c) agar plate screening methods may produce false positives [55]. Furthermore, phytase from Bacillus have been proposed as feed additives for fish diets. The supplementation of $300 \mathrm{U} \mathrm{Kg}^{-1}$ of Bacillus phytase was equivalent to the supplementation of $1000 \mathrm{U} \mathrm{Kg}^{-1}$ acidic commercial phytase [57]. $\beta$-propellers are considered good candidates for fish feed applications due to their optimal $\mathrm{pH}(6-7.5)$, while PAPs and HAPs often have optimal $\mathrm{pH}$ in the acidic range $(2.5-5.5)[15,53]$ Thus, phytase from microbes inhabiting aquaponics systems could be of high economic importance for fish feed formulations.

\section{Conclusions}

The studied aquaponics systems were highly diverse in their microbial community compositions, and the strong variations in the microbial communities within replicates prevented us from statistically demonstrating differences between communities present in fish and plant compartments. Evidence from DNA sequencing and biochemical assays performed on isolated strains showed that, among the fibre-degrading enzymes, cellulases are the most common enzymes expressed, followed by $\beta$-glucanase and xylanase. Phytases production was a far less common trait, with only two isolates showing a consistent increase in extracellular phosphate when grown in broth media supplemented with phytate. $\beta$ propeller appears to be the most ecologically relevant phytase class in our aquaponics systems. Further examination of isolates that showed different enzyme activities are needed (such as $\mathrm{pH}$ range of activity of the different enzymes detected) to assert their potential use either in aquaponics systems or as animal feed additives. Bacilli bacteria are here demonstrated to play a critical role in organic matter cycling in aquaponics systems, which can be a valuable source of niche microbes carrying carbohydrases and phytases enzymes with possible biotechnological applications. 
Author Contributions: D.M.-B.: Conceptualization, methodology, formal analysis, data curation, writing-draft preparation, supervision, project administration, funding acquisition; N.A.-M.: laboratory analysis, writing —original draft preparation; B.A.-S.: laboratory analysis; A.A.-K.: laboratory analysis, R.G.: writing - review and editing; S.D.: writing-review and editing. All authors have read and agreed to the published version of the manuscript.

Funding: This research was funded by Sultan Qaboos University through the project Screening of Omani desert soils for thermostable phytases (IG/AGR/SWAE/19/02) and by The Research Council (TRC) of the Sultanate of Oman through the project Thermostable phytases and carbohydrases of Omani desert soils and their potential for biotechnological application as poultry feed supplements (RC/RG-AGR/SWAE/19/01).

Institutional Review Board Statement: Not applicable.

Informed Consent Statement: Not applicable.

Data Availability Statement: Data used in this manuscript is available through https://www. researchgate.net/profile/Daniel-Menezes-Blackburn, 14 September 2021).

Acknowledgments: In this section, you can acknowledge any support given which is not covered by the author contribution or funding sections. This may include administrative and technical support, or donations in kind (e.g., materials used for experiments).

Conflicts of Interest: The authors declare no conflict of interest.

\section{References}

1. Delaide, B.; Goddek, S.; Gott, J.; Soyeurt, H.; Jijakli, M.H. Lettuce (Lactuca sativa L. var. Sucrine) growth performance in complemented aquaponic solution outperforms hydroponics. Water 2016, 8, 467. [CrossRef]

2. Buzby, K.M.; Waterland, N.L.; Semmens, K.J.; Lin, L.-S. Evaluating aquaponic crops in a freshwater flow-through fish culture system. Aquaculture 2016, 460, 15-24. [CrossRef]

3. Goddek, S.; Espinal, C.A.; Delaide, B.; Jijakli, M.H.; Schmautz, Z.; Wuertz, S.; Keesman, K.J. Navigating towards decoupled aquaponic systems: A system dynamics design approach. Water 2016, 8, 303. [CrossRef]

4. Rakocy, J.; Masser, M.P.; Losordo, T. Recirculating Aquaculture Tank Production Systems: Aquaponics-Integrating Fish and Plant Culture; Oklahoma State University: Brian, TX, USA, 2016.

5. Al-Hafedh, Y.S.; Alam, A.; Beltagi, M.S. Food production and water conservation in a recirculating aquaponic system in Saudi Arabia at different ratios of fish feed to plants. J. World Aquac. Soc. 2008, 39, 510-520. [CrossRef]

6. Coad, M.T.; Petrea, S.M.; Cristea, V.; Dediu, L.; Bandi, C.; Turek-Rahoveanu, M.; Zugravu, A.G.; Rahoveanu, A.T.; Mocuta, D.N. Water Quality in Aquaponic Integrated Systems: An Overview of the Literature Innovation Management and Education Excellence Vision 2020: Regional Development to Global Economic Growth; PUBLONS: London, UK, 2016.

7. Turkmen, G.; Guner, Y. Aquaponic (integrating fish and plant culture) systems. In International Symposium on Sustainable Development, Science Book; Wiley: London, UK, 2010; pp. 657-666.

8. Munguia-Fragozo, P.; Alatorre-Jacome, O.; Rico-Garcia, E.; Torres-Pacheco, I.; Cruz-Hernandez, A.; Ocampo-Velazquez, R.V.; Garcia-Trejo, J.F.; Guevara-Gonzalez, R.G. Perspective for aquaponic systems: “omic" technologies for microbial community analysis. BioMed Res. Int. 2015, 2015, 480386. [CrossRef] [PubMed]

9. Kasozi, N.; Kaiser, H.; Wilhelmi, B. Metabarcoding analysis of bacterial communities associated with media grow bed zones in an aquaponic system. Int. J. Microbiol. 2020, 2020, 8884070. [CrossRef]

10. Rurangwa, E.; Verdegem, M.C. Microorganisms in recirculating aquaculture systems and their management. Rev. Aquac. 2015, 7, 117-130. [CrossRef]

11. Tyson, R.V.; Treadwell, D.D.; Simonne, E.H. Opportunities and challenges to sustainability in aquaponic systems. HortTechnology 2011, 21, 6-13. [CrossRef]

12. Leonard, N.; Blancheton, J.; Guiraud, J. Populations of heterotrophic bacteria in an experimental recirculating aquaculture system. Aquac. Eng. 2000, 22, 109-120. [CrossRef]

13. Schmautz, Z.; Graber, A.; Jaenicke, S.; Goesmann, A.; Junge, R.; Smits, T.H. Microbial diversity in different compartments of an aquaponics system. Arch. Microbiol. 2017, 199, 613-620. [CrossRef]

14. Francis, G.; Makkar, H.P.; Becker, K. Antinutritional factors present in plant-derived alternate fish feed ingredients and their effects in fish. Aquaculture 2001, 199, 197-227. [CrossRef]

15. Menezes-Blackburn, D.; Greiner, R. Enzymes Used in Animal Feed: Leading Technologies and Forthcoming Developments; Wiley Online Library: London, UK, 2014.

16. Council, N.R. Nutrient Requirements of Fish and Shrimp; NRC: Washington, DC, USA, 2011.

17. Da Silva Cerozi, B.; Fitzsimmons, K. Effect of dietary phytase on phosphorus use efficiency and dynamics in aquaponics. Aquac. Int. 2017, 25, 1227-1238. [CrossRef] 
18. Liebert, F.; Portz, L. Nutrient utilization of Nile tilapia Oreochromis niloticus fed plant based low phosphorus diets supplemented with graded levels of different sources of microbial phytase. Aquaculture 2005, 248, 111-119. [CrossRef]

19. Jorquera, M.; Martínez, O.; Maruyama, F.; Marschner, P.; De La Luz Mora, M. Current and future biotechnological applications of bacterial phytases and phytase-producing bacteria. Microbes Environ. 2008, 23, 182-191. [CrossRef]

20. Hill, J.E.; Kysela, D.; Elimelech, M. Isolation and assessment of phytate-hydrolysing bacteria from the DelMarVa Peninsula. Environ. Microbiol. 2007, 9, 3100-3107. [CrossRef]

21. Hien, T.T.T.; Be, T.T.; Lee, C.M.; Bengtson, D.A. Development of formulated diets for snakehead (Channa striata and Channa micropeltes): Can phytase and taurine supplementation increase use of soybean meal to replace fish meal? Aquaculture 2015, 448, 334-340. [CrossRef]

22. Krogdahl, Å.; Hemre, G.I.; Mommsen, T. Carbohydrates in fish nutrition: Digestion and absorption in postlarval stages. Aquac. Nutr. 2005, 11, 103-122. [CrossRef]

23. MR DNA. Shallowater, TX, USA. 2021. Available online: https://www.mrdnalab.com/ (accessed on 1 November 2020).

24. Pardee, A.B.; Jacob, F.; Monod, J. The genetic control and cytoplasmic expression of "inducibility" in the synthesis of $\beta$ galactosidase by E. coli. J. Mol. Biol. 1959, 1, 165-178. [CrossRef]

25. Heuer, H.; Krsek, M.; Baker, P.; Smalla, K.; Wellington, E. Analysis of actinomycete communities by specific amplification of genes encoding 16S rRNA and gel-electrophoretic separation in denaturing gradients. Appl. Environ. Microbiol. 1997, 63, 3233-3241. [CrossRef] [PubMed]

26. Subajini, M.; Sandrasegarampillai, B.; Vasanthy, A. Screening and identification of a thermophilic and alkalophilic bacterium producing xylanase. Adv. Appl. Sci. Res. 2012, 3, 242-250.

27. Maravi, P.; Kumar, A. Isolation, Screening and Identification of Cellulolytic Bacteria from Soil. Biotechnol. J. Int. 2020, 24, 1-8. [CrossRef]

28. Fooladi, J.; Sajjadian, A. Screening the thermophilic and hyperthermophilic bacterial population of three Iranian hot-springs to detect the thermostable $\alpha$-amylase producing strain. Iran. J. Microbiol. 2010, 2, 46-50.

29. Ohno, T.; Zibilske, L.M. Determination of low concentrations of phosphorus in soil extracts using malachite green. Soil Sci. Soc. Am. J. 1991, 55, 892-895. [CrossRef]

30. Huang, H.; Shi, P.; Wang, Y.; Luo, H.; Shao, N.; Wang, G.; Yang, P.; Yao, B. Diversity of beta-propeller phytase genes in the intestinal contents of grass carp provides insight into the release of major phosphorus from phytate in nature. Appl. Environ. Microbiol. 2009, 75, 1508-1516. [CrossRef]

31. Tye, A.; Siu, F.; Leung, T.; Lim, B. Molecular cloning and the biochemical characterization of two novel phytases from B. subtilis 168 and B. licheniformis. Appl. Microbiol. Biotechnol. 2002, 59, 190-197. [PubMed]

32. Huang, H.; Zhang, R.; Fu, D.; Luo, J.; Li, Z.; Luo, H.; Shi, P.; Yang, P.; Diao, Q.; Yao, B. Diversity, abundance and characterization of ruminal cysteine phytases suggest their important role in phytate degradation. Environ. Microbiol. 2011, 13, 747-757. [CrossRef]

33. Ondov, B.D.; Bergman, N.H.; Phillippy, A.M. Interactive metagenomic visualization in a Web browser. BMC Bioinform. 2011, 12, 385. [CrossRef]

34. Hammer, Ø.; Harper, D.A.; Ryan, P.D. PAST: Paleontological statistics software package for education and data analysis. Palaeontol. Electron. 2001, 4, 9.

35. Köhler, J.; Baumbach, J.; Taubert, J.; Specht, M.; Skusa, A.; Rüegg, A.; Rawlings, C.; Verrier, P.; Philippi, S. Graph-based analysis and visualization of experimental results with ONDEX. Bioinformatics 2006, 22, 1383-1390. [CrossRef]

36. Joo, H.-S.; Hirai, M.; Shoda, M. Characteristics of ammonium removal by heterotrophic nitrification-aerobic denitrification by Alcaligenes faecalis No. 4. J. Biosci. Bioeng. 2005, 100, 184-191. [CrossRef]

37. Sharrer, M.J.; Summerfelt, S.T.; Bullock, G.L.; Gleason, L.E.; Taeuber, J. Inactivation of bacteria using ultraviolet irradiation in a recirculating salmonid culture system. Aquac. Eng. 2005, 33, 135-149. [CrossRef]

38. Sugita, H.; Nakamura, H.; Shimada, T. Microbial communities associated with filter materials in recirculating aquaculture systems of freshwater fish. Aquaculture 2005, 243, 403-409. [CrossRef]

39. Leonard, N.; Guiraud, J.; Gasset, E.; Cailleres, J.; Blancheton, J. Bacteria and nutrients-Nitrogen and carbon-In a recirculating system for sea bass production. Aquac. Eng. 2002, 26, 111-127. [CrossRef]

40. Eck, M.; Sare, A.R.; Massart, S.; Schmautz, Z.; Junge, R.; Smits, T.H.; Jijakli, M.H. Exploring bacterial communities in aquaponic systems. Water 2019, 11, 260. [CrossRef]

41. Nishioka, T.; Elsharkawy, M.M.; Suga, H.; Kageyama, K.; Hyakumachi, M.; Shimizu, M. Development of culture medium for the isolation of Flavobacterium and Chryseobacterium from rhizosphere soil. Microbes Environ. 2016, 31, 104-110. [CrossRef] [PubMed]

42. Ladeira, S.A.; Cruz, E.; Delatorre, A.B.; Barbosa, J.B.; Martins, M.L.L. Cellulase production by thermophilic Bacillus sp: SMIA-2 and its detergent compatibility. Electron. J. Biotechnol. 2015, 18, 110-115. [CrossRef]

43. Marimuthu, M.; Sorimuthu, A.; Muruganantham, S. Production and Optimization of Xylanase Enzyme from Bacillus subtilis using Agricultural Wastes by Solid State Fermentation. Int. J. Pharm. Investig. 2019, 9, 169-173. [CrossRef]

44. Subramaniyan, S.; Prema, P. Biotechnology of microbial xylanases: Enzymology, molecular biology, and application. Crit. Rev. Biotechnol. 2002, 22, 33-64. [CrossRef] [PubMed]

45. Shakir, H.A.; Anwar, A.; Irfan, M.; Khan, M.; Ali, S.; Qazi, J.I. Statistical Optimization of Xylanase from Bacillus licheniformis Using Banana Peels in Submerged Fermentation. Iran. J. Sci. Technol. Trans. A Sci. 2020, 44, 981-991. [CrossRef] 
46. Singh, A.; Sharma, D.; Varghese, L.M.; Mahajan, R. Fast flow rate processes for purification of alkaline xylanase isoforms from Bacillus pumilus AJK and their biochemical characterization for industrial application purposes. Biotechnol. Prog. 2020, 36 , e2898. [CrossRef]

47. Pauly, M.; Keegstra, K. Cell-wall carbohydrates and their modification as a resource for biofuels. Plant J. 2008, 54, 559-568. [CrossRef] [PubMed]

48. Irfan, M.; Mushtaq, Q.; Tabssum, F.; Shakir, H.A.; Qazi, J.I. Carboxymethyl cellulase production optimization from newly isolated thermophilic Bacillus subtilis K-18 for saccharification using response surface methodology. AMB Express 2017, 7, 1-9. [CrossRef] [PubMed]

49. Elayaraja, S.; Velvizhi, T.; Maharani, V.; Mayavu, P.; Vijayalakshmi, S.; Balasubramanian, T. Thermostable $\alpha$-amylase production by Bacillus firmus CAS 7 using potato peel as a substrate. Afr. J. Biotechnol. 2011, 10, 11235-11238.

50. Quesada-Ganuza, A.; Antelo-Varela, M.; Mouritzen, J.C.; Bartel, J.; Becher, D.; Gjermansen, M.; Hallin, P.F.; Appel, K.F.; Kilstrup, M.; Rasmussen, M.D. Identification and optimization of PrsA in Bacillus subtilis for improved yield of amylase. Microb. Cell Factories 2019, 18, 1-16. [CrossRef]

51. Van Dijl, J.; Hecker, M. Bacillus subtilis: From soil bacterium to super-secreting cell factory. Microb. Cell. Fact. 2013, 12, 3. [CrossRef]

52. Khan, A.A.; Jilani, G.; Akhtar, M.S.; Naqvi, S.M.S.; Rasheed, M. Phosphorus solubilizing bacteria: Occurrence, mechanisms and their role in crop production. J. Agric. Biol. Sci. 2009, 1, 48-58.

53. Cheng, C.; Lim, B.L. Beta-propeller phytases in the aquatic environment. Arch. Microbiol. 2006, 185, 1-13. [CrossRef]

54. Lim, B.L.; Yeung, P.; Cheng, C.; Hill, J.E. Distribution and diversity of phytate-mineralizing bacteria. ISME J. $2007,1,321$. [CrossRef] [PubMed]

55. Menezes-Blackburn, D.; Jorquera, M.A.; Greiner, R.; Gianfreda, L.; de la Luz Mora, M. Phytases and phytase-labile organic phosphorus in manures and soils. Crit. Rev. Environ. Sci. Technol. 2013, 43, 916-954. [CrossRef]

56. Jorquera, M.A.; Gabler, S.; Inostroza, N.G.; Acuña, J.J.; Campos, M.A.; Menezes-Blackburn, D.; Greiner, R. Screening and characterization of phytases from bacteria isolated from Chilean hydrothermal environments. Microb. Ecol. 2018, 75, 387-399. [CrossRef]

57. Fu, S.; Sun, J.; Qian, L.; Li, Z. Bacillus phytases: Present scenario and future perspectives. Appl. Biochem. Biotechnol. 2008, 151, 1-8. [CrossRef] [PubMed] 